\title{
Case Report \\ Pityriasis Lichenoides Chronica Associated with Herpes Simplex Virus Type 2
}

\author{
Antonio Javier González Rodríguez, Encarnación Montesinos Villaescusa, \\ and Esperanza Jordá Cuevas
}

Departments of Dermatology, Hospital Clínico of Valencia, University of Valencia, Avenida Blasco Ibáñez 17, 46010 Valencia, Spain

Correspondence should be addressed to Antonio Javier González Rodríguez, ajavigo@hotmail.com

Received 23 August 2012; Accepted 23 October 2012

Academic Editors: L. Bianchi, M. J. Fellner, K. Jimbow, and S. Kawara

Copyright (C) 2012 Antonio Javier González Rodríguez et al. This is an open access article distributed under the Creative Commons Attribution License, which permits unrestricted use, distribution, and reproduction in any medium, provided the original work is properly cited.

Introduction. Pityriasis lichenoides is a rare, acquired spectrum of skin conditions of an unknown etiology. Case Report. A 28-year-old man presented with recurrent outbreaks of herpes simplex virus associated with the onset of red-to-brown maculopapules located predominantly in trunk in each recurrence. Positive serologies to herpes simplex virus type 2 were detected. Histopathological examination of one of the lesions was consistent with a diagnosis of pityriasis lichenoides chronica. Discussion. Pityriasis lichenoides is a rare cutaneous entity of an unknown cause which includes different clinical presentations. A number of infectious agents have been implicated based on the clustering of multiple outbreaks and elevated serum titers to specific pathogens (human immunodeficiency virus, cytomegalovirus, Epstein-Barr virus, Toxoplasma gondii, and herpes simplex virus). In our patient, resolution of cutaneous lesions coincided with the administration of antiviral drugs and clinical improvement in each genital herpes recurrence. In conclusion, we report a case in which cutaneous lesions of pityriasis lichenoides chronica and a herpes simplex virus-type 2-mediated disease have evolved concomitantly.

\section{Introduction}

Pityriasis lichenoides is a rare, acquired spectrum of skin conditions of an unknown etiology, although infectious agents have been suspected as etiologic factors.

\section{Case Report}

A 28-year-old man presented with recurrent outbreaks of herpes simplex virus (HSV) type 2 in the form of ulcers on the glans penis associated with the onset of red-tobrown maculopapules located predominantly in trunk in each recurrence. The patient had four recurrences on a twoyear followup (Figure 1(a)).

Positive serologies to HSV type 2 were detected in each outbreak (IgM and IgG). He received acyclovir $400 \mathrm{mg}$ five times a day for 5 days, then a prophylactic dose of $400 \mathrm{mg}$ twice a day; however, after discontinuation of antiviral drug, lesions reappeared.
Histopathological examination of one of the lesions showed epidermal acanthosis, scanty lymphocytic exocytosis, without spongiosis, or focal necrosis. Perivascular infiltrates of lymphocytes with occasional eosinophils and erythrocytic extravasation were seen in the dermis (Figure 1(b)). HSV DNA was not detected in the epidermal keratinocytes or lymphocytes in the biopsy specimen. These findings were consistent with a diagnosis of pityriasis lichenoides chronica.

\section{Discussion}

Pityriasis lichenoides (PL) is a rare cutaneous entity of an unknown cause which includes different clinical presentations. It encompasses a spectrum of clinical presentations ranging from acute papular lesions rapidly evolving to form pseudovesicles and central necrosis (pityriasis lichenoides et varioliformis acuta or PLEVA) to small, scaling, benignappearing papules (pityriasis lichenoides chronica or PLC). PLEVA and PLC are not distinct diseases but are rather 


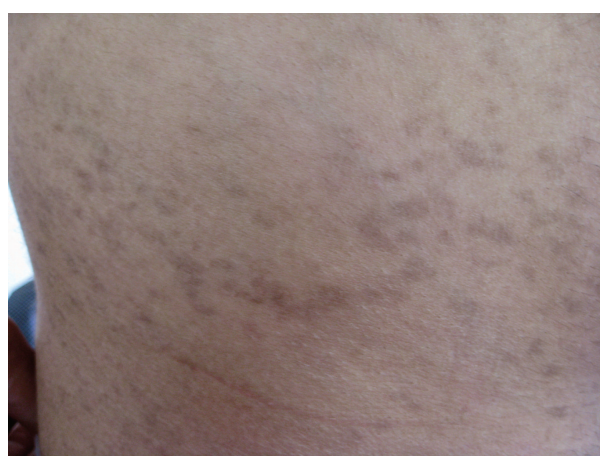

(a)

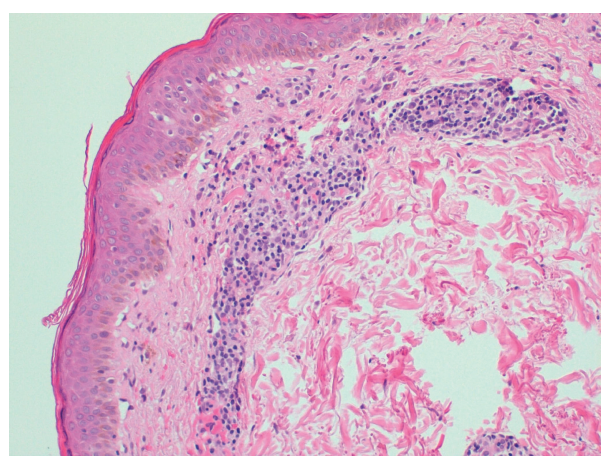

(b)

Figure 1: (a) Red-to-brown maculopapules in trunk. (b) Epidermal acanthosisand scanty lymphocytic exocitosis. Perivascular infiltrates of lymphocytes in dermis (haematoxylin and eosin, original magnification $\times 20$ ).

different manifestations of the same process. The pathogenic mechanism behind PL is unclear although infectious or drug-related hypersensitivity reactions versus lymphoproliferative disorders are the mainstay theories. A number of infectious agents have been implicated based on the clustering of multiple outbreaks and elevated serum titers to specific pathogens, such as human immunodeficiency virus, hepatitis $\mathrm{C}$ virus, cytomegalovirus, Epstein-Barr virus, Toxoplasma gondii, and HSV [1-4], but there has been no consistent finding so far. Recent studies have demonstrated PLEVA to be a benign disorder of activated T-cell lymphocytes. Furthermore, monoclonal rearrangement of the T-cell receptor-gamma (TCR-gamma) genes was repeatedly found both in PLEVA and PLC [5-7].

In our patient, resolution of cutaneous lesions coincided with the administration of antiviral drugs (they remained as residual lesions without scarring) and clinical improvement in each genital herpes recurrence. PLC did not become less severe at successive attacks. Whether this association represents HSV reactivation caused by immune dysfunction related to the skin disease or HSV acting as an antigenic trigger is uncertain.

In conclusion, we report a case in which cutaneous lesions of pityriasis lichenoides chronica and a herpes simplex virus type 2-mediated disease have evolved concomitantly.

\section{References}

[1] P. A. Klein, E. C. Jones, J. L. Nelson, and R. A. Clark, "Infectious causes of pityriasis lichenoides: a case of fulminant infectious mononucleosis," Journal of the American Academy of Dermatology, vol. 49, Supplement 2, pp. 151-153, 2003.

[2] K. S. Tsai, H. J. Hsieh, K. C. Chow, T. Y. Lin, S. F. Chiang, and H. H. Huang, ". Detection of cytomegalovirus infection in a patient with febrile ulceronecrotic Mucha-Habermanns disease," International Journal of Dermatology, vol. 40, pp. 694 698, 2001.

[3] J. J. Smith and G. F. Oliver, "Febrile ulceronecrotic MuchaHabermann disease associated with herpes simplex virus type 2," Journal of the American Academy of Dermatology, vol. 60, no. 1, pp. 149-152, 2009.
[4] B. Zechini, A. Teggi, M. Antonelli et al., "A case report of pityriasis lichenoides in a patient with chronic hepatitis C," Journal of Infection, vol. 51, no. 2, pp. 23-25, 2005.

[5] D. Tomasini, C. F. Tomasini, A. Cerri et al., "Pityriasis lichenoides: a cytotoxic T-cell-mediated skin disorder. Evidence of human parvovirus B19 DNA in nine cases," Journal of Cutaneous Pathology, vol. 31, no. 8, pp. 531-538, 2004.

[6] S. Shieh, D. L. Mikkola, and G. S. Wood, "Differentiation and clonality of lesional lymphocytes in pityriasis lichenoides chronica," Archives of Dermatology, vol. 137, article 305, 2001.

[7] C. Magro, N. Crowson, A. Kovatich, and F. Burns, "Pityriasis lichenoides: a clonal T-cell lymphoproliferative disorder," Human Pathology, vol. 33, article 788, 2002. 


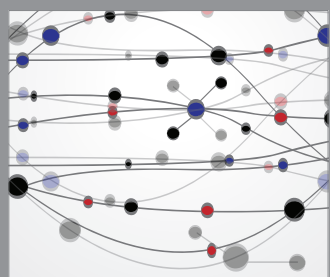

The Scientific World Journal
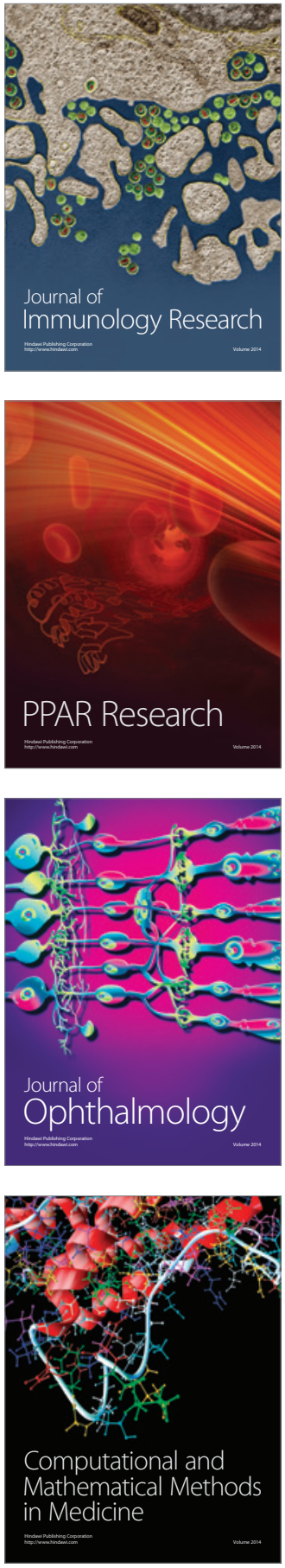

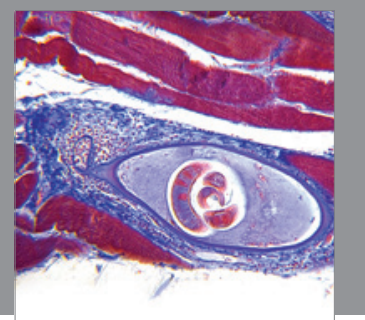

Gastroenterology

Research and Practice
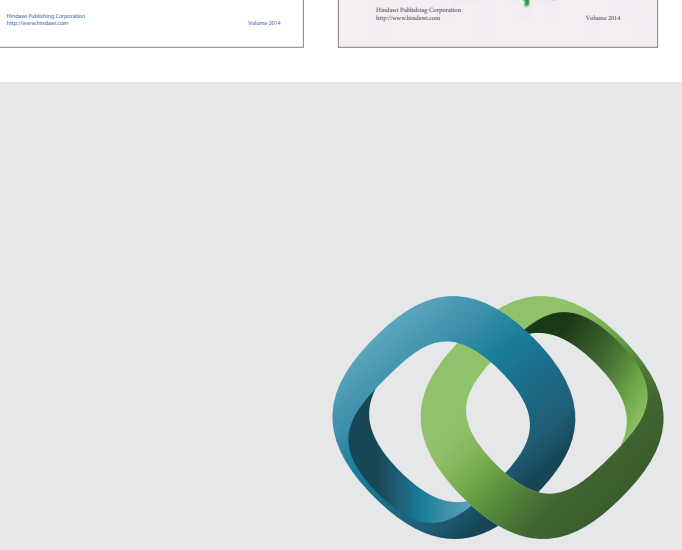

\section{Hindawi}

Submit your manuscripts at

http://www.hindawi.com
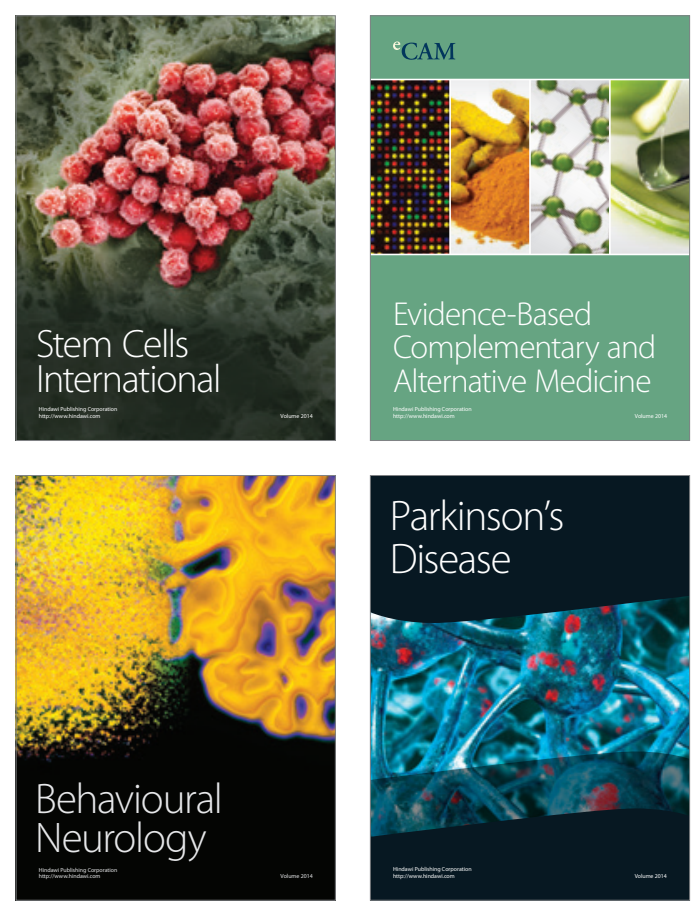

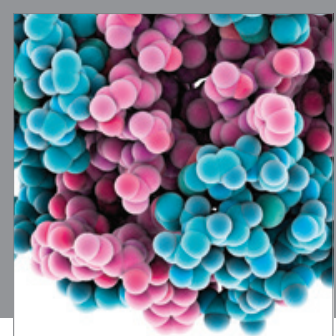

Journal of
Diabetes Research

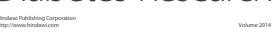

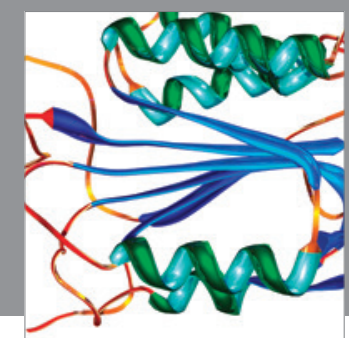

Disease Markers
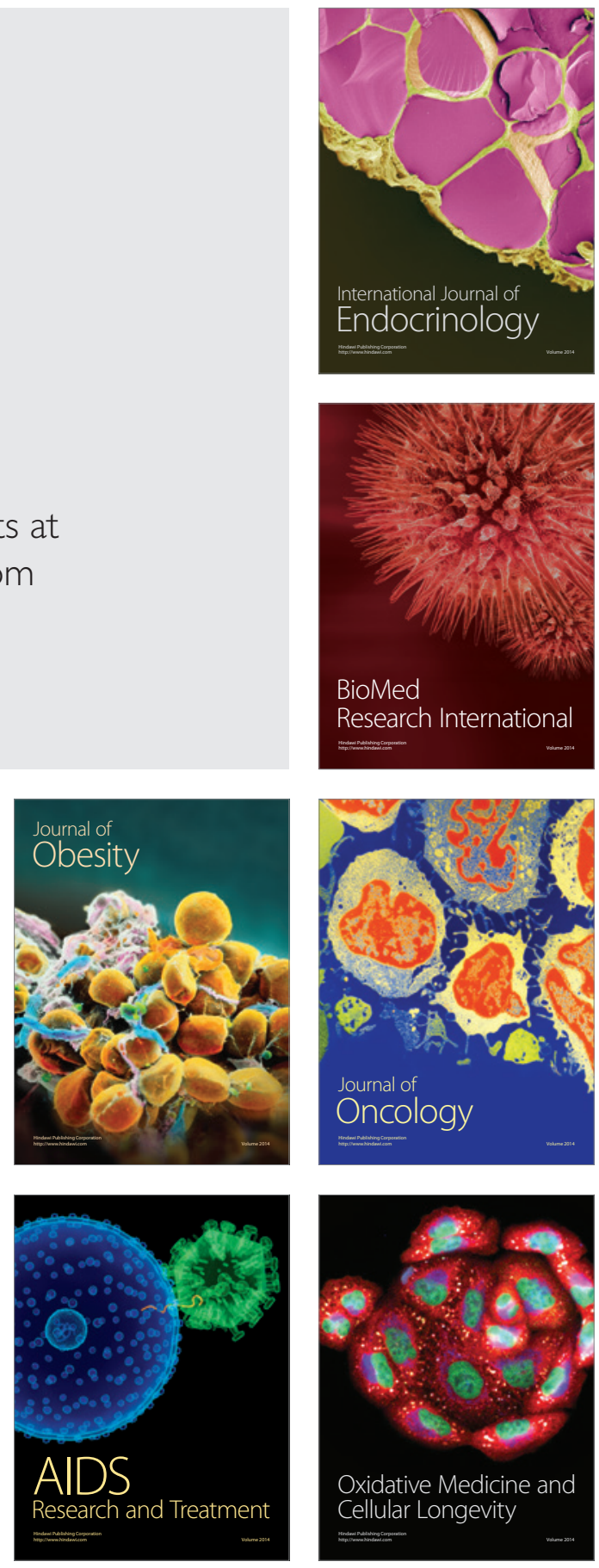